\title{
INFLUENCE OF AGE, MODE OF DELIVERY AND PARITY ON THE PREVALENCE OF POSTERIOR PELVIC FLOOR DYSFUNCTIONS
}

\author{
Sthela Maria MURAD-REGADAS, Francisco Sergio P. REGADAS, Lusmar Veras RODRIGUES, \\ Débora Couto FURTADO, Ana Cecília GONDIM and Íris Daiana DEALCANFREITAS
}

\begin{abstract}
Context - The correlation between vaginal delivery, age and pelvic floor dysfunctions involving obstructed defecation is still a matter of controversy. Objectives - To determine the influence of age, mode of delivery and parity on the prevalence of posterior pelvic floor dysfunctions in women with obstructed defecation syndrome. Methods - Four hundred sixty-nine females with obstructed defecation syndrome were retrospectively evaluated using dynamic 3D ultrasonography to quantify posterior pelvic floor dysfunctions (rectocele grade II or III, rectal intussusception, paradoxical contraction/non-relaxation of the puborectalis and entero/ sigmoidocele grade III). In addition, sphincter damage was evaluated. Patients were grouped according to age $(\leq 50 \mathrm{y} \mathrm{x}>50 \mathrm{y})$ and stratified by mode of delivery and parity: group I ( $\leq 50 \mathrm{y})$ : 218 patients, 75 nulliparous, 64 vaginal delivery and 79 only cesarean section and group II (>50y): 251 patients, 60 nulliparous, 148 vaginal delivery and 43 only caesarean section. Additionally, patients were stratified by number of vaginal deliveries: 0 - nulliparous $(\mathrm{n}=135), 1$ - vaginal $(\mathrm{n}=46),>1$ - vaginal $(\mathrm{n}=166)$. Results - Rectocele grade II or III, intussusception, rectocele + intussusception and sphincter damage were more prevalent in Group II $(P=0.0432$; $P=0.0028 ; P=0.0178 ; P=0.0001$ ). The stratified groups (nulliparous, vaginal delivery and cesarean) did not differ significantly with regard to rectocele, intussusception or anismus in each age group. Entero/sigmoidocele was more prevalent in the vaginal group $\leq 50 \mathrm{y}$ and in the nulliparous and vaginal groups $>50 \mathrm{y}$. No correlation was found between rectocele and the number of vaginal deliveries. Conclusion - Higher age ( $>50$ years) was shown to influence the prevalence of significant rectocele, intussusception and sphincter damage in women. However, delivery mode and parity were not correlated with the prevalence of rectocele, intussusception and anismus in women with obstructed defecation.
\end{abstract}

HEADINGS - Age effect. Parturition. Parity. Pelvic floor. Intususception. Rectocele. Imaging, three-dimensional.

\section{INTRODUCTION}

Several authors have demonstrated an association between pelvic floor dysfunctions (especially involving fecal incontinence, sphincter injury and nerve damage) and age and/or mode of delivery ${ }^{(5,26,28)}$. Anatomical and functional changes of the pelvic floor (anterior compartment) have also been described ${ }^{(12,16,24,25)}$. However, the relation between vaginal delivery, age (post-menopause) and posterior pelvic floor dysfunctions involving obstructed defecation syndrome (ODS) is still a matter of controversy ${ }^{(8,14,17,19,27)}$.

Pelvic floor dysfunctions are best evaluated with dynamic techniques such as magnetic resonance ${ }^{(9,15)}$ and ultrasonography using endorectal $(2,18,19)$ or transperineal ${ }^{(3,7)}$ probes to view the anal canal and pelvis anatomy. Thus, echodefecography, a 3-D dynamic anorectal ultrasonography technique recently developed by Murad-Regadas et al. ${ }^{(19)}$, may be used to evaluate voiding disorders affecting the posterior compartment (rectocele, rectal intussusception, anismus) or the middle compartment (entero/sigmoidocele grade III). The technique has been shown to correlate well with conventional defecography and has been validated in a prospective multicenter study ${ }^{(18,19,22)}$. Proper management of patients with pelvic floor dysfunctions requires extensive knowledge of the specific anatomy and physiopathology involved and, if available, dynamic diagnostic tools.

The aim of the present study was to determine the influence of age, mode of delivery and parity on the prevalence of posterior pelvic floor dysfunctions in women with ODS using echodefecography.

\section{METHODS}

The study was previously approved by the hospital's Research Ethics Committee. From March 2008 to December 2010, 469 female patients with ODS (excessive straining, vaginal splinting and sensation of incomplete evacuation), with a Agachan et al.(1) constipation score of $\geq 6.0$ (range: 6-18) despite

Departamento de Cirurgia, Universidade Federal do Ceará - Fortaleza, CE, Brasil.

Correspondence: Dr. Sthela Ma. Murad-Regadas - Rua Atilano de Moura, 430 - apt. 200 - 60810-180 - Fortaleza, CE, Brasil. E-mail: smregadas@hospitalsaocarlos.com.br 
increased intake of dietary fiber (up $30 \mathrm{~g} /$ day for 3 months), were retrospectively evaluated using echodefecography in order to quantify posterior pelvic floor dysfunctions (significant rectocele grade II or III, rectal intussusception, paradoxical contraction or non-relaxation of the puborectalis muscle, and entero/sigmoidocele grade III) and sphincter injury. Paradoxical contraction or non-relaxation of the puborectalis muscle was considered evidence of anismus.

Patients were grouped according to age (up to 50 years and older than 50 years) and stratified in subgroups by mode of delivery and parity to evaluate the isolated and associated prevalence of posterior pelvic floor dysfunctions. Group I ( $\leq 50 \mathrm{y}): 218$ patients, mean age $40.33 \pm 0.5085$ years (range 16-50), of whom 75 were nulliparous, 64 had undergone one or more vaginal deliveries (mean 2.0; range 1-7) and 79 had had one or more cesarean sections without labor or vaginal deliveries. Group II ( $>50 \mathrm{y}): 251$ patients, mean age $62.69 \pm 0.5162$ years (range 51-79), of whom 60 were nulliparous, 148 had undergone one or more vaginal deliveries (mean 3.1; range 1-8) and 43 had had one or more cesarean sections without labor or vaginal deliveries. To evaluate the relation between rectocele grade II or III and successive vaginal deliveries, the patients were stratified by the number of vaginal deliveries: 135 patients were nulliparous, 46 had had one vaginal delivery and 166 had had more than one vaginal delivery. Patients with previous colorectal or proctological surgery, inflammatory bowel disease, HIV, fecal incontinence, symptoms of stress and urge urinary incontinence, obesity and diabetic or neurological disorders were excluded.

Dynamic 3D anorectal ultrasonography (3-DAUS) was performed with a 3-D ultrasound scanner (Pro-Focus, endoprobe model 2052, B-K Medical ${ }^{\mathbb{Q}}$, Herlev, Denmark) with proximal-to-distal $6.0 \mathrm{~cm}$ automatic scans. Images were acquired by moving two crystals (axial and longitudinal) on the extremity of the transducer, as described in previous publications ${ }^{(18,19,22)}$, producing a merged $3-D$ cube image recorded in real time for subsequent analysis in multiplanar images. Following rectal enema, patients were examined in the left lateral position. Images were analyzed in the axial, sagittal and, if necessary, in the oblique plane by a single colorectal surgeon (SMMR) with experience in 3-DAUS. Three scans were performed:

- Scan 1 - Evaluation of the anatomical integrity of the anal sphincters at rest.

- Scan 2 - The transducer was positioned at $6.0 \mathrm{~cm}$ from the anal verge. The patient was requested to rest during the first 15 seconds, strain maximally for 20 seconds and then relaxes again, with the transducer following the movement. The purpose of the scan was to evaluate the movement of the puborectal muscle and the external anal sphincter during straining, identifying normal relaxation, non-relaxation or paradoxical contraction.

- Scan 3-Following injection of $120 \mathrm{~mL}-180 \mathrm{~mL}$ ultrasound gel into the rectal ampulla, the transducer was positioned at $7.0 \mathrm{~cm}$ from the anal verge. The scanning sequence was the same as in Scan 2, visualizing and quantifying all anatomical structures and functional changes associated with defecation (rectocele and grade, rectal intussusception and sigmoidocele/enterocele grade III).

\section{Statistical analysis}

The collected data were analyzed with the Chi-square test. Age-related variations were evaluated by with Chi-square for trend using SPSS for Windows (version 15.0). The level of statistical significance was set at $P<0.05$.

\section{RESULTS}

The number of women with one or more vaginal deliveries was significantly greater in group II $(>50 \mathrm{y})(P<0.0001)$, but no significant difference was observed with regard to the number of nulliparous women or patients delivered only by cesarean section between group I and II.

The prevalence of pelvic floor dysfunctions (posterior compartment) in both groups of women with ODS is shown in Table 1. However, rectocele grade II or grade III, rectal intussusception, rectocele grade II or III associated with rectal intussusception and occult sphincter injury were more prevalent in group II $(P=0.0432 ; P=0.0028$; $P=0.0178 ; P=0.0001$, respectively). The groups did not differ significantly with regard to anismus, anismus associated with rectocele grade II or III, or entero/ sigmoidocele grade III (Table 2).

TABLE 1. Prevalence of posterior pelvic floor dysfunctions in 469 female patients with obstructed defecation syndrome

\begin{tabular}{lcc}
\hline $\begin{array}{l}\text { Posterior pelvic floor } \\
\text { dysfunctions }\end{array}$ & $\mathbf{n}$ & $(\%)$ \\
\hline $\begin{array}{l}\text { Rectocele grade II or III } \\
\text { Intussusception }\end{array}$ & 260 & $(50.4 \%)$ \\
Anismus or non relaxation & 153 & $(32.6 \%)$ \\
Enterocele/ sigmoidocele & 230 & $(49.0 \%)$ \\
grade III & 23 & $(4.9 \%)$ \\
Rectocele II and III + & 100 & $(21.3 \%)$ \\
$\begin{array}{l}\text { intussusception } \\
\text { Rectocele II and III + anismus }\end{array}$ & 116 & $(24.7 \%)$ \\
Sphincter damage & 51 & $(10.9 \%)$ \\
\hline
\end{tabular}

When comparing nulliparous women to subjects with vaginal deliveries and subjects with cesarean section in each group, the prevalence of rectocele grade II or III, rectal intussusception and anismus was similar. However, entero/sigmoidocele grade III was more prevalent in subjects with vaginal delivery than in nulliparous women or subjects with cesarian section in group I, and more prevalent in subjects with vaginal delivery and nulliparous women than in subjects with cesarian section in group II (Tables 3 and 4). No correlation was found between the prevalence of rectocele grade II or III and the number of vaginal deliveries (Table 5). 
TABLE 2. Prevalence of posterior pelvic floor dysfunctions in female patients with obstructed defecation syndrome by age

\begin{tabular}{lccc}
\hline Posterior pelvic floor dysfunctions & $\begin{array}{c}\text { Group I (n=218) } \\
\text { (up to 50 years) } \\
\mathbf{n}(\%)\end{array}$ & $\begin{array}{c}\text { Group II (n=251) } \\
\text { (older than 50 years) } \\
\mathrm{n}(\%)\end{array}$ & $P$ \\
\hline Rectocele grade II or III & $110(50.5 \%)$ & $150(59.8 \%)$ & 0.0432 \\
Intussusception & $56(25.7 \%)$ & $97(38.6 \%)$ & 0.0028 \\
Anismus or non relaxation & $115(52.7 \%)$ & $115(38.6 \%)$ & 0.1340 \\
Enterocele/sigmoidocele grade III & $9(4.1 \%)$ & $14(5.6 \%)$ & 0.4685 \\
Rectocele II and III + intussusception & $36(16.5 \%)$ & $64(25.5 \%)$ & 0.0178 \\
Rectocele II and III + anismus & $53(24.3 \%)$ & $63(25.1 \%)$ & 0.8437 \\
Sphincter damage & $10(4.6 \%)$ & $41(16.3)$ & 0.0001
\end{tabular}

TABLE 3. Prevalence of posterior pelvic floor dysfunctions in female patients up to 50 years with obstructed defecation syndrome by mode of delivery

\begin{tabular}{|c|c|c|c|c|}
\hline Posterior pelvic floor dysfunctions & $\begin{array}{c}\text { Nulliparous } \\
(\mathrm{n}=75) \\
\mathrm{n}(\%)\end{array}$ & $\begin{array}{c}\text { Vaginal delivery } \\
(\mathrm{n}=64) \\
\mathrm{n}(\%)\end{array}$ & $\begin{array}{c}\text { Cesarean section } \\
(\mathrm{n}=79) \\
\mathrm{n}(\%)\end{array}$ & $P$ \\
\hline Rectocele (grade II or III) & $35(46.7 \%)$ & $39(60.9 \%)$ & $36(45.6 \%)$ & 0.6979 \\
\hline Intussusception & $14(18.7 \%)$ & $19(29.7 \%)$ & $23(29.1 \%)$ & 0.2278 \\
\hline Anismus or non relaxation & $42(56.0 \%)$ & $36(56.2 \%)$ & $37(46.8 \%)$ & 0.4187 \\
\hline Enterocele/sigmoidocele (grade III) & $2(2.7 \%)$ & $7(10.9 \%)$ & $0(0.0 \%)$ & 0.0035 \\
\hline
\end{tabular}

TABLE 4. Prevalence of posterior pelvic floor dysfunctions in female patients older than 50 years with obstructed defecation syndrome by mode of delivery

\begin{tabular}{lcccc}
\hline Posterior pelvic floor dysfunctions & $\begin{array}{c}\text { Nulliparous } \\
(\mathbf{n}=60) \\
\mathbf{n}(\%)\end{array}$ & $\begin{array}{c}\text { Vaginal delivery } \\
(\mathbf{n}=148) \\
\mathbf{n}(\%)\end{array}$ & $\begin{array}{c}\text { Caesarean section } \\
(\mathbf{n}=43) \\
\mathbf{n}(\%)\end{array}$ & $P$ \\
\hline Rectocele (grade II or III) & $33(55.0 \%)$ & $89(60.0 \%)$ & $27(62.8 \%)$ & 0.6979 \\
Intussusception & $23(38.3 \%)$ & $62(41.9 \%)$ & $12(27.9 \%)$ & 0.2526 \\
Anismus or non relaxation & $30(50.0 \%)$ & $64(43.2 \%)$ & $21(48.8 \%)$ & 0.6139 \\
Enterocele/sigmoidocele (grade III) & $7(11.7 \%)$ & $7(4.7 \%)$ & $0(0.0 \%)$ & 0.0307 \\
\hline
\end{tabular}

TABLE 5. Correlation between the prevalence of rectocele grade II or III in female patients with obstructed defecation syndrome and the number of vaginal deliveries

\begin{tabular}{lccc}
\hline & \multicolumn{2}{c}{ Number of vaginal deliveries } \\
\cline { 2 - 4 } Rectocele (grade II or III) & $\begin{array}{c}\text {-nulliparous } \\
(\mathrm{n}=135) \\
\mathrm{n}(\%)\end{array}$ & $\begin{array}{c}1 \text { delivery } \\
(\mathrm{n}=46)\end{array}$ & $\begin{array}{c}>1 \text { delivery } \\
(\mathrm{n}=166) \\
\mathrm{n}(\%)\end{array}$ \\
\hline Present & $68(50.4 \%)$ & $30(65.2 \%)$ & $98(59.0 \%)$ \\
Absent & 67 & 16 & 69 \\
\hline
\end{tabular}

\section{DISCUSSION}

Different definitions and methodologies have been used to evaluate posterior pelvic floor dysfunctions, especially rectocele. However, there is still much controversy regarding factors of prevalence ${ }^{(8,14,15,17,20,27)}$. Thus, while some reports have correlated pelvic floor abnormalities with obstetric trauma ${ }^{(4,10,12,23)}$, others have failed to identify an association between the incidence of such dysfunctions and vaginal delivery ${ }^{(17,20,27)}$. According to Dietz et al. ${ }^{(6,7)}$ true rectocele is a rectovaginal septum defect in younger nulliparous women, the prevalence and size of which appear to be associated with childbirth.

Regadas et al. ${ }^{(21)}$ clearly demonstrated gender-specific differences in anal canal anatomy. Thus, the anterior external anal sphincter is shorter and the gap is longer in females, possibly accounting for the higher incidence of pelvic floor dysfunctions in this gender. Other authors have suggested that age is the main factor increasing the prevalence of anterior pelvic floor dysfunctions in women ${ }^{(8,12)}$. Therefore, the present 
study was designed to analyze the influence of age, mode of delivery and parity on the prevalence of posterior pelvic floor dysfunctions in women with ODS.

The study included 469 female patients presenting with obstructed defecation symptoms, with a mean constipation score of $\geq 6.0$ despite increased intake of dietary fiber. The patients were evaluated with 3-DAUS to assess the posterior pelvic floor for possible dysfunctions. All anatomical structures of the posterior pelvic floor were clearly identified along with changes during straining and voiding disorders with the use of an automatic scanner with a 16-Mhz rotating transducer producing high-resolution multiplanar images (as in magnetic resonance) recorded for subsequent analysis.

Different techniques and imaging methods have been used to evaluate pelvic floor dysfunctions in the anterior, middle and posterior compartment ${ }^{2,3,3,7,8,9,12,14,15,16,17,18,19,20,24,25,27)}$. Because of differences in measurement techniques and anatomical landmarks, some authors describe rectocele as a descent of the rectal ampulla, quantified by correlation with the inferoposterior margin of the symphysis pubis ${ }^{(8,12)}$, while others consider rectocele a herniation of the anterior rectal wall into the posterior vagina, the size of which determines the grade of rectocele ${ }^{(2,3,9,13,15,17,19,20,23,27,29)}$.

Using 3-DAUS, we identified isolated and associated posterior dysfunctions and determined rectocele size. The prevalence of significant rectocele, anismus and rectal intussusception in our population (women with ODS) was similar to that of other series ${ }^{(13,23,29)}$. Rectocele grade II or III, rectal intussusception, rectocele associated with rectal intussusception and sphincter injury were found to be more prevalent in group II $(>50 \mathrm{y})$. In order to rule out vaginal delivery as a confounding factor in the observed positive association between older age and higher prevalence of posterior pelvic floor dysfunctions, we stratified the groups separately according to mode of delivery and parity. The prevalence of rectocele grade II or III, rectal intussusception and anismus was similar when comparing nulliparous women, subjects with vaginal delivery and subjects with cesarian section, despite the large number of patients over $50 \mathrm{y}$ with a history of vaginal delivery (group II), matching findings from other studies $^{(17,20,27)}$. In addition, no relation was observed between the higher prevalence of significant rectocele and increasing number of vaginal deliveries.

Our results support the notion that parity and mode of delivery have no measurable influence on the prevalence of ODS-related posterior dysfunctions. However, tissue atrophy in women over $50 \mathrm{y}$ (post-menopausal) can lead to reduced distensibility ${ }^{(1)}$ and, consequently, increased risk of pelvic floor dysfunctions. Results vary between studies due to differences in population profile, study variables, techniques and tests performed during evaluation ${ }^{(8,14,17,20,27,30)}$. In an analysis of the demographic variables of post-menopausal women and assessment of pelvic prolapse (uterine, cystocele and rectocele) by baseline pelvic examination, Hendrix et al. ${ }^{(12)}$ found that pelvic prolapse, especially cystocele, is common in older women and strongly associated with parity and obesity. Dietz et al. ${ }^{(8)}$ evaluated females with symptoms of urge and stress urinary incontinence and prolapse using 3-D translabial ultrasound and found a weak relation between age, cystocele and rectocele, but the relationship was stronger for uterine prolapse. Using anorectal manometry, radiological measurements of the anorectal angle and perineal descent, Tsunoda et al. ${ }^{(30)}$ compared 25 females with history of at least one vaginal delivery to 6 nulliparous women and demonstrated that perineal descent was more prevalent among multiparous subjects. In a recent study, Kepenekci et al. ${ }^{(14)}$ assessed by questionnaire a sample of women complaining of at least one type of pelvic floor dysfunction (urinary and anal incontinence, constipation and obstructed defecation) and found age, delivery mode and parity to be associated with the prevalence of all pelvic floor dysfunctions.

The present study focused on posterior pelvic floor dysfunctions in ODS patients without fecal incontinence symptoms or anterior compartment dysfunctions. Occult sphincter injury was detected in patients with history of vaginal delivery (patients with previous anorectal surgery and/or cesarean section with labor were excluded). However, in patients with multiple symptoms, a complete evaluation and identification of all dysfunctions are required to choose an appropriate approach.

Anismus, a functional disorder of the striated anal sphincters and the pelvic floor muscles unrelated with age or parity, was observed in both groups. No difference were seen with respect age to entero/sigmoidocele grade III but was more prevalent in younger subjects with history of vaginal delivery (group I) and in older nulliparous women and subjects with history of vaginal delivery (group II). On echodefecography, sigmodocele or enterocele grade III may be identified by visualizing the intestine between the distal rectum or upper anal canal and the vagina during straining.

The present study is relevant as it simultaneously analyzes the influence of age, delivery mode and parity in a population of women with ODS, identifying the prevalence of isolated and associated pelvic floor dysfunctions and occult sphincter damage using echodefecography (3-D dynamic anorectal ultrasonography). Ideally, had it been possible, women in the vaginal delivery subgroup should have been examined with echodefecography before and after delivery and should have been evaluated before and after menopause. On the other hand, the study compares a representative number of nulliparous women to women with vaginal delivery and cesarean section without labor at different ages, identifying factor(s) capable of increasing the prevalence of posterior pelvic floor dysfunctions.

\section{CONCLUSION}

In summary, higher age ( $>50$ years, postmenopausal period) was shown to influence the prevalence of significant rectocele, intussusception and sphincter damage in women. However, delivery mode and parity were not correlated with the prevalence of significant rectocele, intussusception and anismus in women with ODS. 
Murad-Regadas SM, Regadas FSP, Rodrigues LV, Furtado DC, Gondim AC, Dealcanfreitas ID. Influência da idade, tipo de parto e paridade na prevalência das disfunções do assoalho pélvico no compartimento posterior. Arq Gastroenterol. 2011;48(4):265-9.

RESUMO - Contexto - A correlação entre parto vaginal, idade e disfunções do assoalho pélvico em pacientes com evacuação obstruída permanece ainda controverso. Objetivo - Determinar a influência da idade, tipo de parto e paridade na prevalência de disfunções do assoalho pélvico posterior em mulheres com evacuação obstruída. Métodos - Quatrocentas e sessenta e nove mulheres com evacuação obstruída foram avaliadas, retrospectivamente, utilizando ultrassonografia tridimensional dinâmica para quantificar disfunções do assoalho pélvico posterior (retocele grau II ou III, intussuscepção retal, anismus e entero/sigmoidocele grau III) e presença de lesão esfincteriana. As pacientes foram agrupadas de acordo com a idade ( $\leq 50$ anos e $>50$ anos) e estratificadas por tipo de parto e paridade em grupo I ( $\leq 50$ anos): incluindo 218 pacientes ( 75 nulíparas, 64 com partos vaginais e 79 apenas com operações cesarianas) e grupo II (>50 anos): incluindo 251 pacientes (60 nulíparas, 148 com partos vaginais e 43 apenas com cesarianas). Além disso, as pacientes foram estratificadas por número de partos vaginais em nulíparas ( $\mathrm{n}=135)$, com um parto vaginal $(\mathrm{n}=46)$ e com mais de um parto vaginal $(\mathrm{n}=166)$. Resultados - Retocele, intussuscepção, associação de intussuscepção e retocele e lesão esfinceriana foram mais prevalentes no grupo II $(P=0,0432, P=0,0028, P=0,0178, P=0,0001)$. Não houve diferença significante na prevalência de retocele, intussuscepção ou anismus em relação ao tipo de parto e paridade, em cada faixa etária. Êntero/sigmoidocele foi mais prevalente em pacientes com parto vaginal no grupo I e em nulíparas e com parto vaginal no grupo II. Nenhuma correlação foi encontrada entre prevalência de retocele e número de partos vaginais. Conclusão - A idade superior a 50 anos está associada a maior prevalência de retocele, intussuscepção e lesão esfincteriana, no entanto, a paridade e o tipo de parto não se correlacionam com a prevalência de intussuscepção, retocele e anismus em mulheres com evacuação obstruída.

DESCRITORES - Efeito idade. Parto. Paridade. Assoalho pélvico. Intussuscepção. Retocele. Imagem tridimensional.

\section{REFERENCES}

1. Agachan F, Pfeifer J, Wexner SD. Defecography and proctography. Results of 744 patients. Dis Colon Rectum. 1996;39:899-905.

2. Barthet M, Portier F, Heyries L, Orsoni P, Bouvier M, Houtin D, Barriere N, Mambrini P, Salducci J, Grimaud JC. Dynamic anal endosonography may challenge defecography for assessing dynamic anorectal disorders: results of a prospective pilot study. Endoscopy. 2000;32:300-5.

3. Beer-Gabel M, Teshler M, Schechtman E, Zbar AP. Dynamic transperineal ultrasound vs. defecography in patients with evacuatory difficulty: a pilot study. Int J Colorectal Dis. 2004;19:60-7.

4. Brubaker L. Rectocele. Curr Opin Obstet Gynecol. 1996;8:876-9.

5. Deen KI, Kumar D, Williams JG, Olliff J, Keighley MR. The prevalence of ana sphincter defects in faecal incontinence: a prospective endosonic study. Gut. 1993;34:685-8.

6. Dietz H, Steensma A. The role of childbirth in the aetiology of rectocele. BJOG 2006;113:264-7.

7. Dietz HP, Steensma AB. Posterior compartment prolapse on two-dimensiona and three-dimensional pelvic floor ultrasound: the distinction between true rectocele, perineal hypermobility and enterocele. Ultrasound Obstet Gynecol 2005;26:73-7.

8. Dietz HP. Prolapse worsens with age, doesn't it?. Aust N Z J Obstet Gynaecol. 2008;48:587-91

9. Dvorkin LS, Hetzer F, Scott SM, Williams NS, Gedroyc W, Lunniss PJ. Open magnet MR defaecography compared with evacuation proctography in the diagnosis and management of patients with rectal intussusception. Colorectal Dis. 2004; 6:45-53

10. Flet-Bersma RJ, Cuesta Ma. Rectal prolapse, rectal intussusception, rectocele and solitary rectal ulcer syndrome. Gastroenterol Clin North Am. 2001:30:199-222.

11. Goh JT. Biomechanical properties of prolapsed vaginal tissue in preand postmenopausal women. Int Urogynecol J Pelvic Floor Dysfunct. 2002;13:76-9.

12. Hendrix SL, Clark A, Nygaard I, Aragaki A, Barnabei V, McTiernam A. Pelvic organ prolapse in the women's health initiative: gravity and gravidity. Am J Obstet Gynecol. 2002;186:1160-6.

13. Johansson C, Nilsson BY, Holmström B, Dolk A, Mellgren A. Association between rectocele and paradoxical sphincter response. Dis Colon Rectum. 1992;35:503-9.

14. Kepenekci I, Keskinkılıc B, Akınsu F, Cakır P, Elhan AH, Erkek AB, Kuzu MA Prevalence of pelvic floor disorders in the female population and the impact of age, mode of delivery, and parity. Dis Colon Rectum. 2011;54:85-94.

15. Lienemann A, Anthuber C, Baron A, Kohz P, Reiser M. Dynamic MR colpocystorectography assessing pelvic floor descent. Eur Radiol. 1997; 7:1309-17.

16. Meyer S, Schreyer A, De Grandi P, Hohlfeld P. The effects of birth on urinary continence mechanisms and other pelvic-floor characteristics. Obstet Gynecol. 1998;92:613-8.
17. Murad-Regadas S, Peterson TV, Pinto RA, Regadas FS, Sands DR, Wexner SD. Defecographic pelvic floor abnormalities in constipated patients: does mode of delivery matter? Tech Coloproctol. 2009;13:279-83.

18. Murad-Regadas SM, Regadas FS, Rodrigues LV, Souza MH, Lima DM, Silva FR, Filho FS. A novel procedure to assess anismus using three-dimensional dynamic anal ultrasonography. Colorectal Dis. 2007;9:159-65.

19. Murad-Regadas SM, Regadas FS, Rodrigues LV, Silva FR, Soares FA, Escalante RD. A novel three-dimensional dynamic anorectal ultrasonography technique (echodefecography) to assess obstructed defecation, a comparison with defecography. Surg Endosc. 2008;22:974-9.

20. Murad-Regadas SM, Regadas FS, Rodrigues LV, Oliveira L, Barreto RG, de Souza MH, Silva, FR. Types of pelvic floor dysfunctions in nulliparous, vaginal delivery, and cesarean section female patients with obstructed defecation syndrome identified by echodefecography. Int J Colorectal Dis. 2009;24:1227-32.

21. Regadas FS, Murad-Regadas SM, Lima DM, Silva FR, Barreto RG, Souza MH, Regadas Filho FS. Anal canal anatomy showed by three-dimensional anorectal ultrasonography. Surg Endosc. 2007;21:2207-11.

22. Regadas FS, Haas EM, Abbas MA, Marcio Jorge J, Habr-Gama A, Sands D, Wexner SD, Melo-amaral I, Sardiñas C, Lima DM, Sagae EU, Murad-Regadas SM. Prospective multicenter trial comparing echodefecography with defecography in the assessment of anorectal dysfunctions in patients with obstructed defecation. Dis Colon Rectum. 2011;54:686-92.

23. Renzi A, Izzo D, Di Sarno G, De Iuri A, Bucci L, Izzo G, Di Martino N. Cinedefecographic findings in patients with obstructed defection syndrome. A study in 420 cases. Minerva Chir. 2006;61:493-9.

24. Rortveit G, Daltveit AK, Hannestad YS, Hunskaar S; Norwegian EPINCONT Study. Urinary incontinence after vaginal delivery or cesarean section. N Eng J Med. 2003:348:900-7.

25. Serati M, Salvatore S, Khullar V, Uccella S, Bertelli E, Ghezzi F, Bolis P. Prospective study to assess risk factors for pelvic floor dysfunction after delivery. Acta Obstet Gynecol Scand. 2008;87:313-8.

26. Snooks SJ, Swash M, Mathers SE, Henry MM. Effect of vaginal delivery on the pelvic floor: a 5-year follow-up. Br J Surg. 1990;77:1358-60

27. Soares FA, Regadas FS, Murad-Regadas SM, Rodrigues LV, Silva FR, Escalante RD, Bezerra RF. Role of age, bowel function and parity on anorectocele pathogenesis according to cinedefecography and anal manometry evaluation. Colorectal Dis. 2009; 11:947-50.

28. Sultan AH, Kamm MA, Hudson CN, Thomas JM, Bartram CI. Anal-sphincter disruption during vaginal delivery. N Engl J Med. 1993;329:1905-11.

29. Thompson JR, Chen AH, Pettit PD, Bridges MD. Incidence of occult rectal prolapse in patients with clinical rectoceles and defecatory dysfunction. Am J Obstet Gynecol. 2002;187:1494-500.

30. Tsunoda A, Shibusawa M, Kamiyama G, Kusano M, Shimizu Y, Yanaihara T The effect of vaginal delivery on the pelvic floor. Surg Today. 1999;29:1243-7.

Received 24/6/2011. Accepted 21/7/2011. 